Animal Health Research Institute,

Assiut Provincial Laboratory.

\title{
SOME STUDIES ON BACTERIA INDUCTION OF RENAL LESIONS IN CHICKENS
}

(With 11 Tables and 9 Figures)

By

\author{
HEBAT-ALLAH A. MOHAMED \\ and NABA WIA M. SHEHATA
}

(Received at 2/4/2009)

بعض الاراسات على البكتريا المسببة الإصابة في الكلى في الاجاج

هبه الله عبل الحليم محمد ، نبوييه محمود شحاته

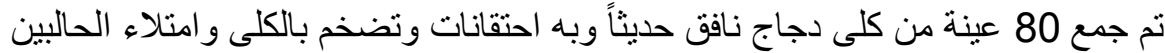

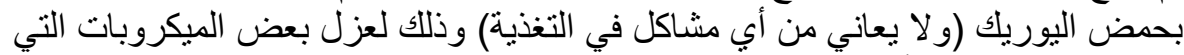

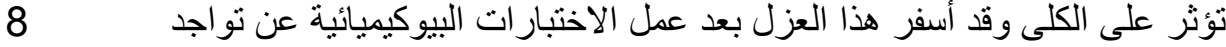

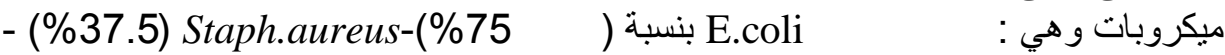
Proteus - (\%15) Klebsiella pneumoniae - (\%31.3) Corynebacterium - (\%8.8) Clostridium Perfringenes (\%11.3) Pseudomons - (\%18.8) Enterococcus faecalis 11 يوم بميكروب E.coli وميكروب Corynebacterium (لارتفاع نسبة عزلهم الهم وكمثال

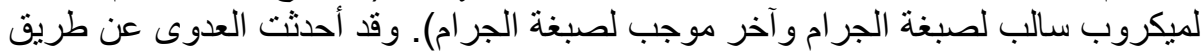

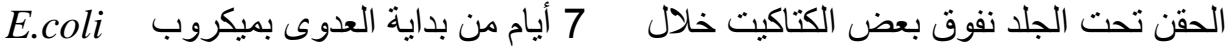

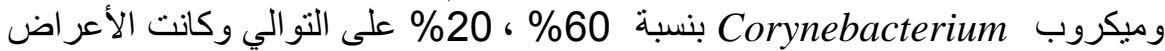

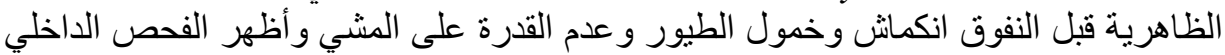

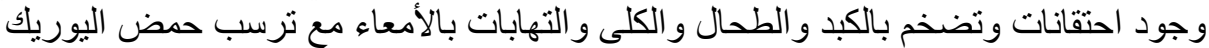

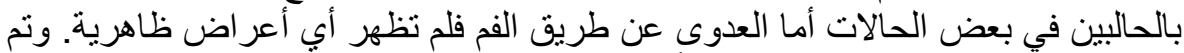

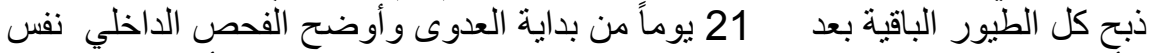

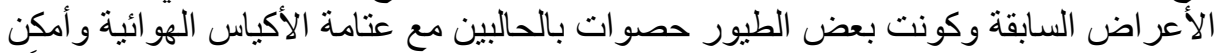

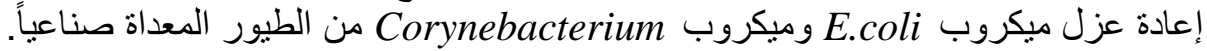

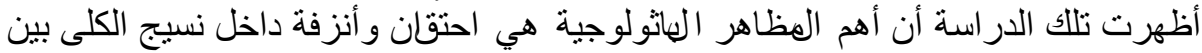

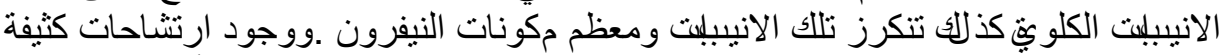

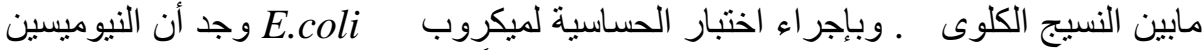

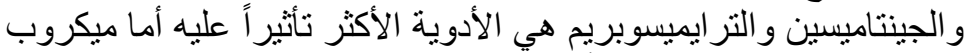
Corynebacterium وجد أن الاريثروميسين و الريفمبين و الجينتاميسين هي الأينين الأدوية الأكثر 
Eighty samples from enlarged congested kidneys were collected from freshly dead chickens from different farms of Assiut Governorate(and didn't suffer from any ration problems). These samples were taken to isolate some bacteria which affect kidneys. After biochemical reactions, the isolation revealed presence of 8 organisms: E.coli at a rate of $(70 \%)$ - Staph. aureus (37.5\%) - Corynebacterium (31.3\%) - Klebsiella (15\%) - Proteus (18.8\%) - Pseudomonas (11.3\%) - Clostridium perfringenes (8.8\%) - Enterococcus faecalis $(6.3 \%)$. Experimental infection of 11 day - old chicken subcutaneously with isolated E.coli and Corynebacterium showed mortality rates of $60 \%$ and $20 \%$ respectively within 7 days postinoculation. Before death birds were depressed, huddling together and couldn't move. Postmortem examination revealed congestion and enlargement of kidneys, liver and spleen and the ureters were filled with urate. Birds which inoculated orally, didn't show any clinical signs. 21 days postinoculation all birds were sacrified, P.M examination revealed congestion and enlargement of kidneys and the ureters were distended with urate. Some birds formed stones in the ureters. Reisolation of the 2 organisms from kidneys of experimentally infected birds was successful. Histopathological study reveled that interstitial nephritis in the form of blood vessel congestion and hemorrhage tubular cell degeneration mononuclear cell infiltration and glumerular hypercellularity are the most permanent lesions in bacterial infected chicken. In vitro sensitivity test revealed that neomycin, gentamycin and trimethoprim are the most effective drugs for E.coli while erythromycin, rifampin and gentamycin are the most effective for Corynebacterium.

Key words: Abnormal kidney, E.coli, staph. aureus, Corynebacterium,

Klebsiella, Proteus, Pseudomonas, Clostridium perfringenes, Enterococcus faecalis experimental infection histopathological study

\section{INTRODUCTION}

Kidney damages either due to infectious agents or non infectious factors are the most frequently diagnosed causes of mortality among chickens. Enlargement of the kidney has been reported in a number of common infectious diseases and nephrosis is said to complicate some of them such as pasteurellosis (Fletcher and Moas 1962) and Pullorum disease (Suganuma 1960). Siller (1964) isolated E. coli and staphylococci from cases of Pyelonephritis in fowl. 
Ginzburg (1975) reisolated Staphylococcus from the Kidneys of experimentally infected chicks. Abd_Alla (1981) mentioned that Klebsiella species cause renal lesions. Mario Podrom (1989) isolated Salmonella typhymurium from congested Kidneys. Jordon (1990) and Randall (1991) stated that Colisepticaemia is associated with nephritis.

Chandra and Singh (1980) reported that nephrosis in poultry is due to infectious agents and nutritional imbalances.

Chandra et al. (1984) a,b cited that the neurogenic- adrenergic effect of urea which increases the Permeability of capillaries, is responsible for edema in the body of bird. Dehydration has been considered an important factor in the precipitation of urate, this may be due to nonavailability of adequate water to flush out the urinary system leading to its clogging. Appearance of nervous symptoms may be the combined effect of hyperuricemia and excessive Production of ammonia in the large intestine caused by degeneration of urea by microbial urease.

This work was designed to cover the following points:

1 - Survey about different bacteria which cause renal lesions in chickens.

2 - Experimental infection of healthy chicks with the most prevalent organisms to show their effect on kidneys of chicks.

3 - Study histopathological picture of naturally and experimentally infected Kidneys of chicks.

4- In vitro sensitivity test to show the most effective drugs on these organisms.

\section{MATERIALS and METHODS}

\section{Materials}

Specimens:

Eighty samples from abnormal Kidneys were collected from freshly dead broiler and balady chickens (4-12 weeks age) from different farms of Assiut Governorate.

\section{Media}

Nutrient agar, MacCon key's agar, blood agar, T.S.I agar, urea agar base, semisolid agar, sugar media for (glucose, sucrose, maltose, lactose, mannitol, sorbitol and fructose) and gelatin.

Reagents and solutions: Methyl red - Kovac's reagent - Voges proskauer, oxidase, urea, 3\% hydrogen peroxide - esculin broth with ferric citrate- sodium hippurate and ninhydrin.

Stain: Gram's stain. 


\section{Pathogenicity test:}

Fifty five, 11 day old balady chicks were used in our experiment. All birds were obtained from the faculty of Agriculture farm in Assiut University.

\section{In vitro antibiotic sensitivity dises:}

Danofloxacin $(5 \mu \mathrm{g})$, gentamycin $(10 \mu \mathrm{g})$, trimethoprim $(5 \mu \mathrm{g})$, ampicillin $(10 \mu \mathrm{g})$, streptomycin $(10 \mu \mathrm{g})$, erythromycin $(15 \mu \mathrm{g})$, neomycin $(30 \mu \mathrm{g})$, oxytetracyclin $(30 \mu \mathrm{g})$, penicillin $(\mathrm{k} 10 \mu \mathrm{g})$, tetracycline $(30 \mu \mathrm{g})$, rifampein $(30 \mu \mathrm{g})$, kanamycin $(30 \mu \mathrm{g})$, and naladixic acid $(30 \mu \mathrm{g})$.

\section{Methods:}

\section{Isolation:}

Direct swabs were taken from abnormal kidneys (have renal lesions) of freshly dead chickens. Each sample was inoculated onto 2 nutrient agar plates, 2 MacConkey's agar plates and 2 blood agar plates. Inoculated plates were incubated aerobically and anaerobically for $48 \mathrm{~h}$, at $37^{\circ} \mathrm{c}$. Suspected colonies were subjected to bacteriological examination to identify the organisms by showing (shape - size colour) of the colonies, typical morphology of the organism by Gram's stain and studying biochemical reactions. Biochemical reactions were done according to Baily \& Scott's (1994), Ellen et al. (1994), Kirk Skeels (1997), Connie\& George (1995), Flacklam and Teixeila (1998) and Wages (2003).

\section{Pathogenicity test:}

Fifty five, 11 day old balady chicks were used, five from them were tested before the experiment and proved to be free from renal lesions. The other fifty birds were divided as follow:

$1-1^{\text {st }}$ group: was ten -11 day old chicks, they were inoculated subcutaneously with $10^{9}$ of bacterial suspension of the isolated E. coli (according to Sokkar et al., 1998)

$2-2^{\text {nd }}$ group: was ten -11 day old chicks, they infected with $3 \times 10^{9}$ of bacterial suspension of the isolated E. coli orally.

$3-3^{\text {rd }}$ group: was five -11 day old chicks, were left as control.

$4-4^{\text {th }}$ group: was ten -11 day old chicks, were infected subcutaneously with $10^{9}$ bacterial suspension of the isolated Corynebacterium pyogenes.

$5-5^{\text {th }}$ group: was ten -11 day old chicks were inoculated orally with $3 \times 10^{9}$ bacterial suspension of isolated Corynebacterium pyogenes.

$6-6^{\text {th }}$ group: was five, 11-day old chicks were left as control.

(according to Sokker et al., 1998). 


\section{In vitro antibiotic sensivity test:}

Susceptibility tests were done using different sensitivity discs against the isolated E. coli and isolated Corynebacterium pyogenes.

\section{Histopathological examination}

Small pieces of Kidneys from naturally and experimentally infected chickens were fixed in $10 \%$ buffered formalin embedded in paraffin and stained with haematoxylin and eosin.

\section{RESULTS}

Postmortem examination of collected chickens with renal lesions revealed enlarged, congested kidneys and ureters were distended with urate.

Bacteriological isolation revealed different colonies in aerobic and anaerobic condition. Gram's stain revealed gram negative bacilli, gram positive bacilli and cocci. From the characters of colonies (shape, size and color which illustrat in Table 1) and gram's stain, we could isolate 8 suspected types of bacteria: E coli. Staph sp, Corynebacterium sp, Proteus sp, Klebsiella sp, Pseudomonas sp, Clostridium sp and Streptococcus sp. Biochemical reactions which done to identify these organisms are illustrated in Tables 2-9.

According to the cellural and colonial morphology and biochemical reaction, the frequency of the isolates were:

- E coli $60 / 80$ isolates (75\%)

- Staph.aureus 30/80 isolates (37.5\%)

- Corynebacterium pyogenes 25/80 isolates (31.3\%)

- Klebsiella pneumoniae 12/80 isolates (15\%)

- Proteus mirabilis 15/80 isolates (18.8\%)

- Pseudomonas aeruoginosa 9/80 isolates (11.3\%)

- Clostridium perfringenes 7/80 isolates (8.8\%)

- Enterococcus faecalis 5/80 isolates (6.3\%) 
So we used E. coli and Corynebacterium pyogenes for Pathogenecity test because they were more prevalence and as an example for gram - positive organism and gram - negative organism.

\section{Pathogenicity Test}

All birds which were inoculated subcutaneously with the isolated E. coli and Corynebacterium pyogenes showed mortality rates of $60 \%$ and $20 \%$ respectively within 7 days postinoculation (PI). Before death, birds were depressed, huddling together and couldn't move. Postmortem examination (PM) revealed turbidity of air sacs, enteritis, congestion and enlargement of liver, spleen and Kidney. The ureteres were filled with urate (Fig, 1 and 2). Birds, which inoculated orally, didn't show any clinical signs. 21 days PI all birds were sacrificed, PM examination revealed congestion and enlargement of Kidneys and the ureters were distended with urate. Some birdes formed stones in the ureters (Fig.3).

There was no sings, lesions or death in control birds.

Reisolation of E. coli and Corynebacterium from Kidneys of experimentally infected birds was successful.

The pathological changes in the kidneys of both natural and experimentally infected birds were the same.

Interstitial nephritis with very prominent dilatation of blood sinuses in between the renal tubules. Congestion and hemorrhage were dominant picture.

There were foci of mononuclear cells in the intertubular space around the glomeruli and blood vessels.

The epithelial cells of some renal tubules showed degenerative changes from cloudy swelling to necrosis. The tubular lumen appeared either empty or contain eosinophilic amorphous material. The glomerular lesions were observed in the form of degeneration of the tufts or hypercelularity.

\section{In vitro sensitivity test}

The effect of the different antibiotics to the isolated E. coli and Corynebacterium is illustrated in tables 10 and 11 . 
Table 1: Showing bacteriological examination:

\begin{tabular}{|c|c|c|c|c|}
\hline $\begin{array}{l}\text { Susbected } \\
\text { colony } \\
\text { NO }\end{array}$ & $\begin{array}{c}\text { colony on } \\
\text { nutrient } \\
\text { agar } \\
\end{array}$ & $\begin{array}{l}\text { Colony on blood } \\
\text { agar }\end{array}$ & $\begin{array}{c}\text { Colony on } \\
\text { MacCon key's } \\
\text { agar } \\
\end{array}$ & Gram's stain \\
\hline \multicolumn{5}{|c|}{ The organism grows aerobically } \\
\hline $1-$ & $\begin{array}{l}\text { Smoth, } \\
\text { white } \\
\text { round } \\
\text { colony }\end{array}$ & Grey round colony & $\begin{array}{l}\text { Rose-Pink colony } \\
\text { with characteristic } \\
\text { coliform smell }\end{array}$ & Gram-negative bacilli \\
\hline \multicolumn{5}{|c|}{ The organism grows aerobically } \\
\hline 2- & $\begin{array}{l}\text { Pigmented } \\
\text { white to } \\
\text { orange } \\
\end{array}$ & $\begin{array}{l}\text { Smoth, round } \\
\text { haemolytic colony }\end{array}$ & 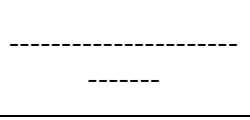 & $\begin{array}{l}\text { Gram- Positive cocci found } \\
\text { in clusters }\end{array}$ \\
\hline \multicolumn{5}{|c|}{ The organism grows aerobically and an aerobically } \\
\hline $3-$ & $\begin{array}{l}\text { Opaque } \\
\text { white pin } \\
\text { point } \\
\text { colony }\end{array}$ & $\begin{array}{l}\text { Haemolytic grey } \\
\text { pin point colony }\end{array}$ & 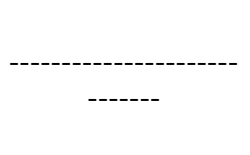 & $\begin{array}{l}\text { Gram-Positive pleomorphic } \\
\text { bacilli and tendency to form } \\
\text { clumps palisade arrangement } \\
\text { are frequently observed }\end{array}$ \\
\hline \multicolumn{5}{|c|}{ The organism grows aerobically } \\
\hline 4- & $\begin{array}{l}\text { Greenish } \\
\text { diffusible } \\
\text { pigment } \\
\text { with fruity } \\
\text { smell } \\
\end{array}$ & $\begin{array}{l}\text { Produce beta } \\
\text { haemolysis }\end{array}$ & $\begin{array}{l}\text { Blue green flat } \\
\text { round colony }\end{array}$ & Gram-negative rod \\
\hline \multicolumn{5}{|c|}{ The organism grows anaerobically } \\
\hline $5-$ & $\begin{array}{l}\text { Small } \\
\text { white } \\
\text { colony }\end{array}$ & $\begin{array}{l}\text { Small, } \\
\text { nonhaemolytic } \\
\text { colony } \\
\end{array}$ & $\begin{array}{l}\text { White pin point } \\
\text { colony }\end{array}$ & $\begin{array}{c}\text { Gram-Positive spherical } \\
\text { bacteria occurlng singly, in } \\
\text { pairs or short chains }\end{array}$ \\
\hline \multicolumn{5}{|c|}{ The organism grows anaerobically } \\
\hline $6-$ & $\begin{array}{l}\text { Small flat } \\
\text { colony with } \\
\text { irregular } \\
\text { edge }\end{array}$ & $\begin{array}{l}\text { Haemolytic colony } \\
\text { with double zone }\end{array}$ & --------------------- & $\begin{array}{l}\text { Short to intermediate gram- } \\
\text { positive rods }\end{array}$ \\
\hline \multicolumn{5}{|c|}{ The organism grows aerobically } \\
\hline 7- & $\begin{array}{l}\text { Grey } \\
\text { Colony }\end{array}$ & No hoemolysis & $\begin{array}{l}\text { Large pink } \\
\text { mucoid colony } \\
\text { (lactose } \\
\text { fermenter) }\end{array}$ & Gram - negative bacilli \\
\hline \multicolumn{5}{|c|}{ The organism grows aerobically } \\
\hline $8-$ & $\begin{array}{l}\text { Swarming } \\
\text { appearance } \\
\text { on the } \\
\text { surface } \\
\text { with fishy } \\
\text { smell }\end{array}$ & $\begin{array}{l}\text { Non- haemolytic } \\
\text { colony and turns } \\
\text { blood agar brown }\end{array}$ & $\begin{array}{c}\text { Compact pale non } \\
\text { - lactose } \\
\text { fermenter and } \\
\text { edges are } \\
\text { irregular }\end{array}$ & Gram - negative rod \\
\hline
\end{tabular}


Tables (2-9) showing the results of biochemical reactions:

Table 2: For organism No.1

\begin{tabular}{|l|c|c|}
\hline \multicolumn{1}{|c|}{ Biochemical tests } & Result & Suspected organism \\
\hline - H2S production & - & E. coli \\
- Indole & + & \\
- Methyl red & + & \\
- Voges - proskauer & - & \\
- Urea & - & \\
- Simmone's citrate & - & \\
- Gelatin liquefaction & - & \\
- Sugar fermentation & + & \\
$\qquad$ Glucose & + & \\
$\qquad$ Lactose & + & \\
$\bullet$ Mannitol & + & \\
- Sucrose & $+/-$ & \\
\hline
\end{tabular}

Table 3: For organism No.2

\begin{tabular}{|l|c|c|}
\hline \multicolumn{1}{|c|}{ Biochemical tests } & Result & Suspected organism \\
\hline - Coagulase & + & Staphylococcus aureus \\
- Voges - proskauer & + & \\
- Catalase & + & \\
- Gelatin - liquefaction & + & \\
- Fermentation of sugars: & + & \\
- Sucrose & + & \\
- Glucose & + & \\
- Lactose & + & \\
- Fructose & + & \\
- Mannitol & + & \\
$\bullet$ Maltose & & \\
\hline
\end{tabular}

Table 4: For organism No.3

\begin{tabular}{|l|c|c|}
\hline \multicolumn{1}{|c|}{ Biochemical tests } & Result & Suspected organism \\
\hline - Catalase & - & Corynebacterium-pyogenes \\
- H2S production & - & \\
- Indole & - & \\
- Voges - proskauer & - & \\
- Methyl red & - & \\
- Gelatin - liquefaction & + & \\
- Litmus milk & Acidified and & \\
- Fermentation of sugars: & coagulated & \\
$\qquad \quad$ Glucose & + & \\
$\bullet$ Lactose & + & \\
$\bullet$ Maltose & + & \\
- Motility & - & \\
\hline
\end{tabular}


Table 5: For organism No.4

\begin{tabular}{|l|c|c|}
\hline \multicolumn{1}{|c|}{ Biochemical tests } & Result & Suspected organism \\
\hline - Catalase & + & Pseudomonas aeruginosa \\
- Oxidase & + & \\
- Urea & + & \\
- Methyl red & - & \\
- Voges - proskauer & - & \\
- Indole & - & \\
- Litmus milk & + & \\
- Glucose Fermentation & + & \\
- Motility & & \\
\hline
\end{tabular}

Table 6: For organism No.5

\begin{tabular}{|l|c|c|}
\hline \multicolumn{1}{|c|}{ Biochemical tests } & Result & Suspected organism \\
\hline - Esculin_hydrolysis & + & Enterococcus faecalis \\
- Catalase & - & \\
- Fermentation of sugars: & + & \\
- Lactose & + & \\
- Mannitol & - & \\
- Sucrose & + & \\
- Sorbitol & - & \\
- Lotility arabinose & - & \\
- Groth at $10^{\circ} \mathrm{c}$ and $45^{\circ} \mathrm{c}$ & + & \\
\hline
\end{tabular}

Table 7: For organism No.6

\begin{tabular}{|l|c|c|}
\hline Biochemical tests & Result & Suspected organism \\
\hline - Litmus milk reaction & + & Clostridium perfringenes \\
- Gelatin Liquefaction & + & \\
- sugar Fermentation: & & \\
$\bullet$ Glucose & + & \\
- Lactose & + & \\
$\bullet$ Sucrose & + & \\
- Motility & - & \\
\hline
\end{tabular}


Table 8: For organism No.7

\begin{tabular}{|l|c|c|}
\hline \multicolumn{1}{|c|}{ Biochemical tests } & Result & Suspected organism \\
\hline - Simmon's citrate & + & Klebsiella pneumoniae \\
- H2S production & - & \\
- Indole & - & \\
- Methyl red & + & \\
- Voges - proskauer & + & \\
- Urea & + & \\
- Sugar Fermentation: & + & \\
$\quad$ G Glucose & - & \\
- Lactose & - & \\
\hline
\end{tabular}

Table 9: For organism No.8

\begin{tabular}{|l|c|c|}
\hline \multicolumn{1}{|c|}{ Biochemical tests } & Result & Suspected organism \\
\hline - Methyl red & + & Proteus mirabilis \\
- Urea & + & \\
- Indole & - & \\
- Vogus - proskauer & - & \\
- H2S production & + & \\
- Gelatin Liquefaction & + & \\
- Glucose Fermentation: & + & \\
- Motility & + & \\
\hline
\end{tabular}

Table 10: Illustrate in vitro sensitivity test of the isolated E.coli

\begin{tabular}{|c|c|}
\hline Antibiotic discs & Sensitivity of E.coli isolates \\
\hline Neomycin & +++ \\
\hline Gentamycin & +++ \\
\hline Trimethoprim & +++ \\
\hline Kanamycin & ++ \\
\hline Naladixic acid & + \\
\hline Tetra cycline & - \\
\hline Streptomycin & - \\
\hline Ampicillin & - \\
\hline
\end{tabular}

Table 11: Illustrate in vitro sensitivity test of the isolated Corynebacterium

\begin{tabular}{|c|c|}
\hline Antibiotic discs & Sensitivity of Corynebacterium isolates \\
\hline Erythromycin & +++ \\
\hline Rifampin & +++ \\
\hline Gentamycin & +++ \\
\hline Penicillin & ++ \\
\hline Tetracyclin & ++ \\
\hline Oxytetracycline & ++ \\
\hline Danofloxacin & - \\
\hline Kanamycin & - \\
\hline
\end{tabular}


Assiut Vet. Med. J. Vol. 55 No. 122 July 2009 


\section{LEGENED OF FIGURES}

Fig. 1: $\mathrm{H}$ and $\mathrm{E}$ stained kidney section from natural case Show Blood vessel engorged with blood

Fig. 2: $\mathrm{H}$ and $\mathrm{E}$ stained kidney of experimentally infected case show inter tubular blood vessel congestion and hemorrhage.

Fig. 3: $\mathrm{H}$ and $\mathrm{E}$ stained kidney section from natural case Show Tubular necrosis cytoplamsmic vaculation with pcknotic nucleuses.

Fig. 4: $\mathrm{H}$ and $\mathrm{E}$ stained kidney of experimentally infected case show tubular necrosis

Fig. 5: $\mathrm{H}$ and $\mathrm{E}$ stained kidney of experimentally infected case show inter tubular mononuclear cell infiltration

Fig. 6: $H$ and $E$ stained kidney of experimentally infected case show glumerular hypercellularity 
Assiut Vet. Med. J. Vol. 55 No. 122 July 2009 


\section{DISCUSSION}

In our study we could isolate 8 orgnisms from renal lesions: E. coli, Corynebacterium, Staph. aureus, Klebsiella pneumoniae, Proteus mirabilis Pseudomonas aeruginosa, Clostridium perfringems and Enterococcus faecalis. We somewhat in agreement with Sokkar et al. (1998) who isolated only E. coli, Staph. aureus and Corynebacteriun from chickens with renal lesions. But Siller (1964) isolated E. coli and Staph. only, while Ginzburg (1975) reisolated Staph. from the kidneys of experimentally infected chicks. On other hand, Jordan and Randal (1991) isolated E.coli only. We differ with Mario Modrom (1989) who isolated Salmonella typhymurium from congested kidneys and Fletcher and Moas (1962) who said that nephrosis is complicated of pasteurellosis and pullorum disease.

Experimental infection of 11- day old chicks subcutaneously with isolated E. coli and Corynebacterium revealed enlargement congested kidneys and ureters dilated and distended with urates. This result is similar to that observed by Sokkar et al. (1998) but in our experiment there was mortality in birds within 7 doys P.l and we also noticed formation of stones in the ureters of some birds.

The microscopic changes in the kidney of all infected birds either experimentally or naturally were mainly interstitial nephritis. These finding are similar to those of Siller (1964) and Randal (1991). Similar histopathologic picture were recorded by many other investigators for some bacterial species other than those used in our study. For instance Sugnama (1960) claimed that in pullurum disease there were interstitial nephritis. Rahamathulaand Mohyudeen (1973) described interstitial nephritis with tubular degeneration and necrosis in pullet disease. Randal (1991) showed that chlamydiosis causes glomerulonephritis.

In vitro sensitivity test we found that neomycin gentamycin and trimethoprim are the most effective drugs for E. coli this result is similar to that observed by Sokkar et al. (1998) while erythromycin, rifampin and gentamycin are most effective for Corynebocterium we in agreement with Lynda (2008) in this result.

In our study we concluded that the gross pathological lesions observed in the kidneys and microscopic changes were not related to the inoculated organism. So hygienic measures ore necessary to decrease infectious organism and try to reduce bacterial contamination in drinking water and avoid overcrowding and stress factors. 


\section{REFERENCES}

Abd_Alla, O.A.M (1981): Histopathological studies on poultry following artificial infection by Klebsiella M.V.SC. Clinical Pathology. Cairo University.

Bailey and Scott's (1994): Differentiation among selected Enterococcus spp and Streptococci and related genera In: Diagnostic Microbiology. Section 26P. 345, $9^{\text {th }}$ Edition. Edited by Ellen. J. B., lance, P.R. and Sydney, F.M.

Chandra, M. and Singh, B.L. (1980): Incidences and pathology of nephritis in domestic fowl in punjob. Indian J. Poult. Sci. 15: 125-131.

Chandra, M.; Singh, G.L. and Ahuja, S.P. (1984a): Renal and biochemical changes produced in broilers by high-protein, high calcium, urea-containing and vitamin-A deficient diet. Avian Dis. 28: 1-11.

Chandra, M.; Singh, G.L. and Ahuja, S.P. (1984b): Hematological changes in Nephritis in poultry induced by diets high in protein, high in calcium, containing urea, or deficient in vitamin A. Poult. Sci. 63: 710-716.

Connie, M.R. and George, M. (1995): Classification of strepto coccus and Enterococcus In: Diagnostic Microbiology P. 343-344.

Ellen, J.O.; Baron lance, R; Peterson and Finegold, S.M. (1994): Diagnostic Microbiology. P. 321-331 $9^{\text {th }}$ Ed.

Facklam, R.R. and Teixeira, L.M. (1998): Enterococcus In: Topley \& Wilson's in Microbiology and Microbial infections. Chapter 29.P. 674 Vol. 2 Edited by: Leslie Collier, Balows, A. and Sussman, 9th Edition.

Fletcher, R.D. and Maas, H.J.L. (1962): Acute fowl choler in a connecticut flock. Description of the isolation of Pasteurella multocida. Tijdschrift Voor Diergeneeskunde 87, 1125-1128.

Ginzburg, V.V. (1975): Differentiation of staphylococci isolated from fowls. Vet. Moscow 8, 167.

Jordan, F.T.W. (1990): Poultry Diseases. 3rd Ed. Bailliere Tindail and cox. London.

Kirk Skeeles, J. (1997): Staphlococcosis In: Diseases of Poultry 10th Ed. Edited by calnek, B.W. lowa State univ. press, Ames, IA PP. 247-253. 
Lynda, A.F. (2008): Corynebacterium infections. MD, Associated Clinical Professor, Department of internal Medicine, University of California at San Contributor.

Mario Modrom, M. (1989): An outbreak of paratyphoid in laying hens (case report). Avian Disease. 34, 221-223.

Rahmathulla, P.M. and Mohyudeen, S. (1973): Studies on gouty nephritis in poultry. Indian Vet. Journal 50, 841-844.

Randall, C.J. (1991): A color atlas of diseases and disorders of the domestic fowl and turkey. Wolfe Medical Publication, London.

Siller, W.G. (1964): The pathology of pyelonephritis in the fowl. Vet. Sciences 5, 323-331.

Sokkar, S.M.; Mohamed, M.A. and Atawia, M. (1998): Experimental induction of renal lesions in chickens. Berl. Munch. Tierarztl. Wschr. 111, 161-163.

Suganuma, Y. (1960): Histological studies on serositis of pullorum disease. Japanese J. of Vet. Science 22, 175-182.

Wages, D.P. (2003): Enterococcosis In: Diseases of Poultry. Chapter 24.

P. 809-811. Edited br calnek B.W. John Barnes H., Mcdouglad, C.W. and Saif.Y.M. 
Fig 1\&2: Showing congested, enlarged kidney and the urerers are filled with urate in experimentally infected chick.

Fig 3: Experimentally infected chick formed stones in the ureter. 